\title{
Ethnobotanical studies on the Khiamniungan tribe in Tuensang district of Nagaland, Northeast India: Ethnomedicinal plants
}

\author{
Aosanen Ozukum, Sapu Changkija ${ }^{1}$ and S.K. Tripathi ${ }^{2}$ \\ Department of Forestry, Mizoram University, Aizawl-796004, Mizoram, India \\ ${ }^{1}$ Department of Genetics and Plant Breeding, Nagaland University, Medziphema-797106, Nagaland, India \\ ${ }^{2}$ Communicating author; e-mail: sk_tripathi@rediffmail.com
}

[Received 10.06.2019; Revised \& accepted 28.06.2019; Published 30.06.2019]

\begin{abstract}
This paper reports an Ethnobotanical study that focused on the traditional medicinal plants used by the Khiamniungan tribe living in the Tuensang district of Nagaland. The study was conducted during the period $2017-2018$ and is reported for the first time. The study design include oral interview, group discussions with village elders, medicine practitioners and personal observation of plants in use. A total of 76 species belonging to 48 families and 68 genera were recorded which were used as medicinal plants by the Khiamniungan tribe of Nagaland. According to the study, leaves, barks, seeds, flowers, shoots are some of the important plant parts which were dominantly used as medicine for various sickness and ailments. A brief account of the genera, local name, parts used and mode of uses are presented in this paper in the form of table.
\end{abstract}

Key words: Ethnobotany, Khiamniungan tribe, Nagaland, Northeast India

\section{INTRODUCTION}

American botanist John Harshberger first coin the term "ethnobotany" in 1896 as the study of plants used by primitive and aboriginal people. Since then it has been deûned as the traditional knowledge of indigenous communities of the surrounding plant diversity and the study of how the people of a particular culture and region make use of indigenous plants. The deûnition of ethnobotany can be summed up in four words: people, plants, interactions, and uses (Abbasi et al. 2012). Ethnobotany is the use of plants in material or abstract form among ethnic communities or tribal people. Sometimes, it is regarded as ethnographical or anthropological or tribal botany (Shah 2008). Ethnobotanists explore how plants are used as food, shelter, medicine, and clothing, for hunting, and in religious ceremonies. According to Sofowora (1982), around $60-85 \%$ of the population in every developing country is rely only on traditional medicines. As per the analysis by Park et al. (2012), the practice of traditional medicine is widespread in China, India, Japan, Pakistan, Sri Lanka, Thailand, and Korea. In China, traditional medicine accounts for around $40 \%$ of all health care delivered and is used to treat roughly 200 million patients annually (WHO 1999). In Ethiopia, plants are used as a source of medicine and have been in practice from generations to treat different ailments due to its long history (Pankhurst 1965). These traditional medical practices and remedies are recorded in oral tradition and in early medico-religious manuscripts and traditional pharmacopoeias, which, according to the estimates of some historians, date back to the $15^{\text {th }}$ century A.D. (WHO 2001).

India is a vast country with a variety of topographies, climates, vegetation, and people. Forests, grasslands, wetlands, coastal and marine and deserts form the major 
ecosystems in India. The country constitutes about $21.05 \%\left(692,027 \mathrm{~km}^{2}\right)$ of its total geographical area (FSI 2011). When it comes to ethnobotanical practices in India, we can consider two groups of people, those living in small cities or rural villages and tribal peoples who live in remote villages. India has about 563 tribal communities having age-old traditional knowledge through their long association with the forests (BSI 2019) with 50 million people belongs to 550 tribal communities (Shah 2008). They have accumulated valuable knowledge the use of wild plants and have been practicing since time-immemorial, to satisfy their everyday needs to sustain. The Indian subcontinent, which records one of the oldest civilizations, harbor many traditional health care systems. Besides Ayurveda, other traditional methods and folklore systems of health care were developed in the different time periods in the subcontinent, where more than 7500 plant species were used for medicinal purposes (Pandey \& Tripathi 2017).

The state of Nagaland lies between $25^{\circ} 102 \mathrm{~N}$ and $27^{\circ} 42 \mathrm{~N}$ latitude and between $93^{\circ} 152 \mathrm{E}$ and $95^{\circ} 202 \mathrm{E}$ longitudes covering an area of $16,579 \mathrm{sq} \mathrm{km}$ in northern extension of Arakan Yoma Ranges with altitude ranges from 194-3048 m AMSL. It shares international boundary with Myanmar to the east, state of Assam to the west, Arunachal Pradesh and parts of Assam to the north and Manipur to the south. Noklak sub-division of Tuensang district is the homeland of Khiamniungan tribe that lies between $26^{\circ} 142 \mathrm{~N}$ latitude and $94^{\circ} 492$ E longitude with total area of $2,536 \mathrm{sq} \mathrm{km}$ or $15.3 \%$ of the state's area. It is the largest district and located in the easternmost part of Nagaland and is home to Tuensang: Chang, Khiamniungan, Sangtam and Yimchungru tribes and a sub-tribe Tikhir of Yimchungru. Each of these tribes has its own rich culture and tradition.

Khiamniungan tribe is one of the 16 tribes in Nagaland inhibiting the eastern part of the state and in North-west of Myanmar. Agriculture is the main occupation of the Khiamniungan people besides rearing livestocks. The area is very rich in floral diversity and many wild plants with medicinal properties those are yet to be explored. They live in clusters in villages and due to inaccessibility and remoteness of the place, people mostly depend on natural resources of the region for their existence. There is an enormous wealth of knowledge of medicinal plants among these people which they have developed through their age long trial and error methods and orally passed information to their younger generations. The aim of the present paper is to highlight some of the important medicinal plants used by the Khiamniungan tribe for the treatment of their various diseases and ailments.

\section{MATERIALS AND METHOD}

Extensive Ethnobotanical survey was carried out among the Khiamniungan tribe of Nagaland under Tuensang hill district and gathered information about the medicinal plants, those that are traditionally used by the local peoples for the treatment of various sickness and ailments. Informations through oral interviews were gathered in the study site with local medicine practitioners, spiritual healers, village elders, group discussions and personal observations of plants in use were undertaken. The plants named by the participants were recorded. Informations included vernacular names in different tribal languages as for some species vernacular name was not available in Khiamniungan language. Habit, parts used and modes of uses were also collected. Proper written consent, PIC was also taken from the local councils of the village where the data was collected after explaining the purpose of the work. The recorded specimens were processed into mounted herbarium sheets following Jain \& Rao (1977) and were identified using various literatures which includes Kanjilal et al. (1934 - 1940), Prain (1903), Hooker (1872 - 1897) Hara \& Williams (1979), Hara et al. $(1978,1982)$, Grierson \& Long $(1983,1987)$ and Noltie $(1994,2000)$. The 
specimens collected were submitted to Nagaland university herbarium for future studies. For correct nomenclature and family delimitations, www.theplantlist.org has been largely consulted for the recorded plant species.

\section{RESULTS}

A total of 76 species of plants were recorded during the present survey which was used as medicinal plants by the Khiamniungan tribe of Nagaland. These are enumerated below alphabetically in Table 1 along with their scientific names, family, local names, parts used and mode of uses. Most of the Local names are inscripted using Ao tribal language along with some addition of Angami and Sumi tribal language of Nagaland.

Table 1. List of plants used as traditional medicines by Khiamniungan tribe of Tuensang Hill District of Nagaland.

\begin{tabular}{|c|c|c|}
\hline $\begin{array}{l}\text { Scientific Name [Family]/ Local } \\
\text { name }\end{array}$ & $\begin{array}{c}\text { Parts } \\
\text { used }\end{array}$ & Mode of Uses \\
\hline $\begin{array}{l}\text { Abelmoschus moschatus Medic. } \\
\text { [Malvaceae]; Mein sentsurep (Ao) }\end{array}$ & Seeds & $\begin{array}{l}\text { Young leaves are used as vegetables. Barks are used } \\
\text { in making ropes. Leaves sometimes used as wrappers } \\
\text { to cover food items. Powdered seeds are applied on } \\
\text { wound and bites of venomous reptiles. }\end{array}$ \\
\hline $\begin{array}{l}\text { Acacia pennata (L.) Willd. } \\
\text { [Leguminosae]; Chakrang-aing } \\
\text { (Ao) }\end{array}$ & Bark, leaves & $\begin{array}{l}\text { Bark is made into paste and applied to snake bite and } \\
\text { scorpion sting; leaves juice extract is mixed with milk } \\
\text { and served to infants during indigestion; leaves paste } \\
\text { is used as haemostatic. }\end{array}$ \\
\hline $\begin{array}{l}\text { Aconitum ferox Wall. ex Ser. } \\
\text { [Ranunculaceae]; Meri-mezem } \\
\text { (Ao) }\end{array}$ & Whole plant & $\begin{array}{l}\text { Arrows are dip into concentrated juice extraction of } \\
\text { the plant is used in hunting to hunt wild animals. }\end{array}$ \\
\hline $\begin{array}{l}\text { Justicia adhatoda L. } \\
\text { [Acanthaceae]; Septsunaro (Ao) }\end{array}$ & Whole plant & $\begin{array}{l}\text { The extraction by boiling plant material is used for } \\
\text { treatment of respiratory ailments such as cold and } \\
\text { fever. Leave decoction is consumed orally for the } \\
\text { treatment of constipation and stomachache. It is used } \\
\text { as Antispasmodic and diuretic. }\end{array}$ \\
\hline $\begin{array}{l}\text { Ageratum conyzoides }(\mathrm{L} .) \mathrm{L} . \\
\text { [Compositae]; Imchenriza (Ao) }\end{array}$ & $\begin{array}{l}\text { Leaves and } \\
\text { roots }\end{array}$ & $\begin{array}{l}\text { Leaves are crush and the paste is applied to cure cuts } \\
\text { and sores. Root extract is taken orally as anthelmintic. } \\
\text { It is anti-inflammatory and anti-allergic. }\end{array}$ \\
\hline $\begin{array}{l}\text { Albizia chinensis (Osbeck) Merr. } \\
\text { [Leguminosae]; Mokok (Ao) }\end{array}$ & $\begin{array}{l}\text { Bark and } \\
\text { leaves }\end{array}$ & $\begin{array}{l}\text { The gum is applied on the forehead to cure headache. } \\
\text { Infusion of the bark and leaf extract is used as lotion } \\
\text { for skin burn and scabby. Bark is use as anthelmintic. }\end{array}$ \\
\hline $\begin{array}{l}\text { Allium sativum } \mathrm{L} . \\
\text { [Amaryllidaceae]; Lasung (Ao) }\end{array}$ & Bulb & $\begin{array}{l}\text { It is used as a best medicine for hypertension and also } \\
\text { used to reduce or eliminate fever. It is used to kill } \\
\text { worms from the body, stimulate flow of saliva and } \\
\text { helps in digestion. It is also used to prevent ticks and } \\
\text { other insect bites. }\end{array}$ \\
\hline $\begin{array}{l}\text { Allium chinense G.Don } \\
\text { [Amaryllidaceae]; Tejanglasung } \\
\text { (Ao) }\end{array}$ & $\begin{array}{l}\text { Bulbs and } \\
\text { leaves }\end{array}$ & $\begin{array}{l}\text { The juice extracted from the plant is used as moths } \\
\text { and other insect repellent. Bulbs and leaves are either } \\
\text { consumed raw or cooked and is used for the treatment } \\
\text { of fever, stomachache, sore throat and cough. It is also } \\
\text { used for the treatment of diarrhoea, dysentry and } \\
\text { chest pain. }\end{array}$ \\
\hline $\begin{array}{l}\text { Alstonia scholaris (L.) R.Br. } \\
\text { [Apocynaceae]; Lazarongpang } \\
\text { (Ao) }\end{array}$ & $\begin{array}{l}\text { Leaves and } \\
\text { bark }\end{array}$ & $\begin{array}{l}\text { Juice extracted from the leaves and barks are mixed } \\
\text { with sugarcane and consume for treating ulcers in the } \\
\text { stomach and gastric disorders. Latex is also used for } \\
\text { ceremonial inscription and the wood is used for } \\
\text { carving effigies kept in the grave of a rich man or } \\
\text { warrior. }\end{array}$ \\
\hline
\end{tabular}




\begin{tabular}{|c|c|c|}
\hline $\begin{array}{c}\text { Scientific Name [Family]/ Local } \\
\text { name }\end{array}$ & $\begin{array}{c}\text { Parts } \\
\text { used }\end{array}$ & Mode of Uses \\
\hline $\begin{array}{l}\text { Amblovenatum opulentum J.P. } \\
\text { Roux [Thelypteridaceae]; } \\
\text { Maachai (Ao) }\end{array}$ & Leaves & $\begin{array}{l}\text { Leaves paste mixed with Hypericum japonicum is } \\
\text { applied on toothache to relieve pain and kill the } \\
\text { maggot in the teeth. They are also used for the } \\
\text { treatment of other oral ailments. }\end{array}$ \\
\hline $\begin{array}{l}\text { Aristolochia indica L. } \\
\text { [Aristolochiaceae]; Antsüknü (Ao) }\end{array}$ & $\begin{array}{l}\text { Leaves and } \\
\text { tender } \\
\text { shoots. }\end{array}$ & $\begin{array}{l}\text { Paste of tender shoots applied in bone fractures. The } \\
\text { paste is also applied on wound and bites of venomous } \\
\text { reptiles specially scorpion and snake bites. It is also } \\
\text { used for the treatment of respiratory ailments such as } \\
\text { cold and cough. }\end{array}$ \\
\hline $\begin{array}{l}\text { Artemisia nilagirica (C.B. Clarke) } \\
\text { Pamp. [Compositae]; Antsüksüba } \\
\text { (Ao) }\end{array}$ & Aerial parts & $\begin{array}{l}\text { Plant extract mixed with decoction of Camellia } \\
\text { sinensis is given for treatment of malaria. Plant is also } \\
\text { used as insecticides. Used in asthma, antispasmodic, } \\
\text { aphrodisiac, expectorant and febrifuge. Leaves are } \\
\text { used as haemostatic. }\end{array}$ \\
\hline $\begin{array}{l}\text { Artocarpus lacucha Buch.-Ham. } \\
\text { [Moraceae]; Sungkepsali (Ao) }\end{array}$ & $\begin{array}{l}\text { Barks and } \\
\text { seeds }\end{array}$ & $\begin{array}{l}\text { Seeds have a purgative effect, powdered bark is } \\
\text { applied in wounds. Barks mixed with barks of Ficus } \\
\text { semicordata with lime are eaten as "pan" stimulant. }\end{array}$ \\
\hline $\begin{array}{l}\text { Asparagus officinalis L. } \\
\text { [Asparagaceae]; Asangshi (Ao) }\end{array}$ & Root stock & $\begin{array}{l}\text { Juice extract of roots is taken orally as blood purifier, } \\
\text { diuretic and tonic. Tubers and young shoots are used } \\
\text { as vegetables. }\end{array}$ \\
\hline $\begin{array}{l}\text { Asparagus racemosus Willd. } \\
\text { [Asparagaceae]; Aspregos (Ao) }\end{array}$ & Tubers & $\begin{array}{l}\text { It is Antidiarrhic, antiseptic, diuretic, nutritive and } \\
\text { tonic. The decoction of the whole plant is consumed } \\
\text { for treating diarrhea, dysentery with blood, epilepsy } \\
\text { and haemophilic disorder. }\end{array}$ \\
\hline $\begin{array}{l}\text { Bauhinia variegata } \mathrm{L} . \\
\text { [Leguminosae]; Noksangtsüben/ } \\
\text { Purnoklu (Ao) }\end{array}$ & $\begin{array}{l}\text { Bark, } \\
\text { flowers and } \\
\text { roots }\end{array}$ & $\begin{array}{l}\text { The juice extracted from the bark and flower is used } \\
\text { for the treatment of diarrhea, dysentry and other } \\
\text { stomach disorders the paste of the bark is used for } \\
\text { treating cuts and wounds and other related skin } \\
\text { diseases. Traditionally root is used as an antidote to } \\
\text { snake poisoning and other insect bites. Sometimes } \\
\text { flower and flower buds is boiled and eaten as } \\
\text { vegetables. }\end{array}$ \\
\hline $\begin{array}{l}\text { Begonia flaviflora } \text { H.Hara } \\
\text { [Begoniaceae]; Kokralik (Ao) }\end{array}$ & Whole plant & $\begin{array}{l}\text { Paste of the leaves is warmed and applied to treat } \\
\text { mouth ulcer, bristle in the tongue; juice extract is } \\
\text { drunk as astringent, to cure diarrhea and dysentery; } \\
\text { leaves are also eaten as vegetable. }\end{array}$ \\
\hline $\begin{array}{l}\text { Betula alnoides Buch.-Ham. ex } \\
\text { D.Don [Betulaceae]; Entsung/ } \\
\text { Ongpangselum (Ao) }\end{array}$ & Bark & $\begin{array}{l}\text { Bark is aromatic, chewed for digestion, crushed and } \\
\text { soaked in water overnight to bath during body-ache } \\
\text { and fever. }\end{array}$ \\
\hline $\begin{array}{l}\text { Bidens biternata (Lour) Merr. \& } \\
\text { Sherff. [Compositae]; Mesakra- } \\
\text { moli (Ao) }\end{array}$ & Aerial parts & $\begin{array}{l}\text { Aerial parts of plant is boiled and taken orally for } \\
\text { diarrhea and dysentery. }\end{array}$ \\
\hline $\begin{array}{l}\text { Bidens pilosa L. [Compositae]; } \\
\text { Mesakra-moli (Ao) }\end{array}$ & Aerial parts & $\begin{array}{l}\text { Plant is used for the treatment of leprosy and various } \\
\text { skin diseases. Seeds are anthelmintic. It is diuretic } \\
\text { and is used in kidney problems. }\end{array}$ \\
\hline $\begin{array}{l}\text { Bryophyllum pinnata (Lam.) } \\
\text { Oken [Crassulaceae]; Nokchamoli } \\
\text { (Ao) }\end{array}$ & Aerial parts. & $\begin{array}{l}\text { The juice extracted from the plant is used for the } \\
\text { treatment of dysentery, gastric trouble, cuts and } \\
\text { wounds, insect bites, headache, influenza, and skin } \\
\text { diseases of dog. }\end{array}$ \\
\hline $\begin{array}{l}\text { Callicarpa arborea } \text { Roxb. } \\
\text { [Lamiaceae]; Kachet/ Pajat (Ao) }\end{array}$ & $\begin{array}{l}\text { Bark and } \\
\text { twig }\end{array}$ & $\begin{array}{l}\text { Bark of this plant is chewed with the bark of Ficus } \\
\text { silhetensis as stimulant and also the juice extract is } \\
\text { used as red dye. Bark paste is applied as poultice to } \\
\text { treat headache. The juice extract of the young twigs } \\
\text { is used for the treatment of gastric problems. }\end{array}$ \\
\hline
\end{tabular}




\begin{tabular}{|c|c|c|}
\hline $\begin{array}{c}\text { Scientific Name [Family]/ Local } \\
\text { name }\end{array}$ & $\begin{array}{c}\text { Parts } \\
\text { used }\end{array}$ & Mode of Uses \\
\hline $\begin{array}{l}\text { Chloranthus elatior Link } \\
\text { [Chloranthaceae]; Ongchinaro } \\
\text { (Ao) }\end{array}$ & Leaves & $\begin{array}{l}\text { Paste extracted from the leaves is applied in the } \\
\text { wound of tiger and dog bites as antidote. }\end{array}$ \\
\hline $\begin{array}{l}\text { Clerodendrum infortunatum L. } \\
\text { [Lamiaceae]; Shatimanajay (Ao) }\end{array}$ & Leaves & $\begin{array}{l}\text { Leaf paste is used in rheumatism, ulcer and skin } \\
\text { diseases. Decoction of leaves is used in malaria. } \\
\text { Fresh leaves are consumed directly for the treatment } \\
\text { of diarrhea and headache. Leave paste is used for the } \\
\text { treatment of snake and dog bites. Juice extracts are } \\
\text { applied to kill lice in heads. }\end{array}$ \\
\hline $\begin{array}{l}\text { Cheilocostus speciosus (J.Koenig) } \\
\text { C.D. Specht [Costaceae]; Alar } \\
\text { naro (Ao) }\end{array}$ & Root stock & $\begin{array}{l}\text { Plant paste is used as anti-maggot in animals, as } \\
\text { anthelmintic and ophthalmic. It is also used in fever, } \\
\text { anaemia, rheumatism, skin diseases and urinary } \\
\text { troubles. Rhizome juice is given traditionally with } \\
\text { sugar to treat leprosy and to relief headache. }\end{array}$ \\
\hline $\begin{array}{l}\text { Commelina benghalensis L. } \\
\text { [Commelinaceae]; Akhovepü } \\
\text { (Sumi) }\end{array}$ & Leaves & $\begin{array}{l}\text { Decoction of leaf is used in boils, burns, cough, used } \\
\text { against muscular pain and in tonsilities. The plant is } \\
\text { bitter, emollient, refrigerant and laxative, used in } \\
\text { leprosy. It is also used in sores and snake bites. }\end{array}$ \\
\hline $\begin{array}{l}\text { Dicranopteris linearis (Burm.f.) } \\
\text { Underw. [Gleicheniaceae]; } \\
\text { Kajangtong (Ao) }\end{array}$ & Whole plant & $\begin{array}{l}\text { Decoction of plant is used during fever and epilepsy. } \\
\text { It is used in asthma, to increase fertility in women and } \\
\text { as anthelmintic. }\end{array}$ \\
\hline $\begin{array}{l}\text { Dioscorea bulbifera } \text { L. } \\
\text { [Dioscoreaceae]; Ninangcha/ } \\
\text { Sureshe (Ao) }\end{array}$ & $\begin{array}{l}\text { Tuber and } \\
\text { leaves }\end{array}$ & $\begin{array}{l}\text { Tubers are used for the treatment of jaundice and } \\
\text { head-ache. It is diuretic and anthelmintic. } \\
\text { Ocassionally, leaves are often used by steam } \\
\text { distillation for the treatment of conjunctivitis }\end{array}$ \\
\hline $\begin{array}{l}\text { Dioscorea pentaphylla L. } \\
\text { [Dioscoreaceae]; Atsüng (Ao) }\end{array}$ & Tuber & $\begin{array}{l}\text { Tubers are edibles and tonic. The decoction of the } \\
\text { whole plant is applied to swellings and boils }\end{array}$ \\
\hline $\begin{array}{l}\text { Elsholtzia communis Colt. \& } \\
\text { Hems. [Lamiaceae]; Napa (Ao) }\end{array}$ & Whole plant & $\begin{array}{l}\text { Whole plant is consumed directly for the treatment of } \\
\text { hypertension and the extracted paste are applied in } \\
\text { cuts and wounds. The plant and flowers are used for } \\
\text { flavoring curry. Plant extracts are applied on heads to } \\
\text { drive out fleas. }\end{array}$ \\
\hline $\begin{array}{l}\text { Erythrina arborescens Roxb. } \\
\text { [Leguminosae]; Mangkotsürong/ } \\
\text { Tzüpentong (Ao) }\end{array}$ & Bark & $\begin{array}{l}\text { Bark is powdered and are used for the treatment of } \\
\text { biliousness, itch, fever, rheumatism, asthma and } \\
\text { leprosy. In ancient times, tribal hang the skull after } \\
\text { head hunting in this tree. Alters are erected under this } \\
\text { tree where the community priest perform their rituals. }\end{array}$ \\
\hline $\begin{array}{l}\text { Eurya acuminata } \mathrm{DC} \text {. } \\
\text { [Pentaphylacaceae]; Alumeset } \\
\text { (Ao) }\end{array}$ & $\begin{array}{l}\text { Leaves and } \\
\text { bark }\end{array}$ & $\begin{array}{l}\text { Juice extract of tender leaves is used to } \\
\text { relieve dysentry and diarrhea. Leaves are also eaten } \\
\text { as vegetables. Bark and leaves are crushed and } \\
\text { soaked in water overnight and used as green-yellow } \\
\text { dye. It is also mixed with juice extract of Rubia } \\
\text { sikkimensis to yield an excellent red dye. }\end{array}$ \\
\hline $\begin{array}{l}\text { Ficus hispida L.f. [Moraceae]; } \\
\text { Poksok (Ao) }\end{array}$ & $\begin{array}{l}\text { Leaves, bark, } \\
\text { root and fruit }\end{array}$ & $\begin{array}{l}\text { Fresh leaves are consumed directly for the treatment } \\
\text { of dysentery and intestinal worm infection. Leave } \\
\text { paste are applied skin diseases, vitiligo, cuts and } \\
\text { wounds. Occasionally green fruits are taken as } \\
\text { vegetable. }\end{array}$ \\
\hline $\begin{array}{l}\text { Ficus semicordata } \text { Buch.-Ham ex } \\
\text { Sm. [Moraceae]; Koronem (Ao) }\end{array}$ & $\begin{array}{l}\text { Leaves, roots } \\
\text { and bark }\end{array}$ & $\begin{array}{l}\text { Decoction of leaves is used for the treatment of } \\
\text { jaundice. The juice extracted from the roots is } \\
\text { applied to treat headaches, sometimes fevers and } \\
\text { menstrual disorders. The bark, combined with young } \\
\text { leaves of Schima wallichii, is used to treat gastric } \\
\text { problems. }\end{array}$ \\
\hline
\end{tabular}




\begin{tabular}{|c|c|c|}
\hline $\begin{array}{c}\text { Scientific Name [Family]/ Local } \\
\text { name }\end{array}$ & $\begin{array}{c}\text { Parts } \\
\text { used }\end{array}$ & Mode of Uses \\
\hline $\begin{array}{l}\text { Gmelina arborea } \text { Roxb. } \\
\text { [Lamiaceae]; Ikongtong/ Zukong } \\
\text { (Ao) }\end{array}$ & $\begin{array}{l}\text { Leaves, bark } \\
\text { and root }\end{array}$ & $\begin{array}{l}\text { Leave paste is applied to relieve from headache. The } \\
\text { decoction of the root is used for the treatment of snake } \\
\text { bite and scorpion sting. Leaf and bark are used for } \\
\text { stomach trouble and root decoction as blood purifier. }\end{array}$ \\
\hline $\begin{array}{l}\text { Gynocardia odorata } \mathrm{R} . \mathrm{Br} . \\
\text { [Achariaceae]; Satsüng (Ao) }\end{array}$ & Seeds & $\begin{array}{l}\text { Powdered seeds mixed with oil are used to treat skin } \\
\text { diseases. }\end{array}$ \\
\hline $\begin{array}{l}\text { Gynura nepalensis DC. } \\
\text { [Compositae]; Yiatsuyi (Ao) }\end{array}$ & Whole plant & $\begin{array}{l}\text { Plant paste are applied on cuts and wounds to stop } \\
\text { bleeding. }\end{array}$ \\
\hline $\begin{array}{l}\text { Hodgsonia macrocarpa (Blume.) } \\
\text { Cogn. [Cucurbitaceae]; Assa (Ao) }\end{array}$ & Fruits & $\begin{array}{l}\text { The bulb of the fruits is applied to cure bacterial } \\
\text { infection and bulb juice is drank to cure malarial } \\
\text { infections. Cotyledons of seeds is a delicacy eaten } \\
\text { after roasting and made into various curry. Leaves are } \\
\text { used to feed silk worms. }\end{array}$ \\
\hline $\begin{array}{l}\text { Holboellia latifolia Wall. } \\
\text { [Berberidaceae]; Shingo mongo } \\
\text { (Ao) }\end{array}$ & Fruits & Fruits are eaten to treat stomach ailments and as tonic. \\
\hline $\begin{array}{l}\text { Houttuynia cordata Thunb. } \\
\text { [Saururaceae]; Alimoli/ Nokna } \\
\text { (Ao) }\end{array}$ & Whole plant & $\begin{array}{l}\text { Juice extract of the plant is taken for the treatment of } \\
\text { ulcer, dysentry, diarrhea, as blood purifier and skin } \\
\text { diseases. Plants are crushed and spread in chicken } \\
\text { coop to keep away fleas. The whole plant is eaten as } \\
\text { vegetable. }\end{array}$ \\
\hline $\begin{array}{l}\text { Hydnocarpus kurzii (King) Warb. } \\
\text { [Achariaceae]; Yimsungjang (Ao) }\end{array}$ & $\begin{array}{l}\text { Bark and } \\
\text { seeds }\end{array}$ & $\begin{array}{l}\text { Paste of the seeds is used to treat leprosy and other } \\
\text { skin diseases. Juice of bark is taken during malaria } \\
\text { fever }\end{array}$ \\
\hline $\begin{array}{l}\text { Hypericum japonicum Thunb. } \\
\text { [Hypericaceae]; Ao-chani (Ao) }\end{array}$ & Whole plant & $\begin{array}{l}\text { Juice extracted from the plant are astringent, } \\
\text { alternative and vulnerary. They are also used to treat } \\
\text { asthma, dysentery and skin diseases. It is believed } \\
\text { that, stacking of plants in the door ways drive away } \\
\text { evil spirits. Paste extracted from the plant is mixed } \\
\text { with Amphineuron opulentum are applied for } \\
\text { toothaches. }\end{array}$ \\
\hline $\begin{array}{l}\text { Juglans regia L. [Juglandaceae]; } \\
\text { Aka tong (Ao) }\end{array}$ & $\begin{array}{l}\text { Leaves, bark } \\
\text { and fruit. }\end{array}$ & $\begin{array}{l}\text { Fruit used as tonic and in rheumatism. Leaves and } \\
\text { bark are anthelmintic. }\end{array}$ \\
\hline $\begin{array}{l}\text { Justicia thyrsiformis Hardw. } \\
\text { [Phlogacanthus thyrsiflorus Roxb. } \\
\text { ex Hardw. Mabb.], [Acanthaceae]; } \\
\text { Metecüse (Angami) }\end{array}$ & Leaves & $\begin{array}{l}\text { Decoction of leaves is used for the treatment of } \\
\text { bronchial diseases, fever, diarrhea, dysentery and } \\
\text { stomach trouble. It is used as diuretic, expectorant, in } \\
\text { whooping cough and sedative. }\end{array}$ \\
\hline $\begin{array}{l}\text { Leucosceptrum canum Sm. } \\
\text { [Lamiaceae]; Anuzamechepa (Ao) }\end{array}$ & $\begin{array}{l}\text { Leaves and } \\
\text { inflorescence }\end{array}$ & $\begin{array}{l}\text { The white cottony tomentum scraped from the leaves } \\
\text { are applied as haemostatic. Inflorescence are soaked } \\
\text { in water and is taken as astringent, stimulant and } \\
\text { tonic. }\end{array}$ \\
\hline $\begin{array}{l}\text { Mahonia pycnophylla }(\text { Fedde }) \\
\text { Takeda }[\text { Berberidaceae }] \\
\text { Sungnenra }(\mathrm{Ao})\end{array}$ & $\begin{array}{l}\text { Bark and } \\
\text { fruits }\end{array}$ & $\begin{array}{l}\text { A decoction of the bark is used as eye drops to treat } \\
\text { inflammations of the eyes. Fruits are taken for the } \\
\text { treatment of dysentery. }\end{array}$ \\
\hline $\begin{array}{l}\text { Molineria capitulata(Lour.) } \\
\text { Kuntz. [Hypoxidaceae]; Koritong } \\
\text { (Ao) }\end{array}$ & Roots & $\begin{array}{l}\text { It is used as a remedy during dilation of pupils and } \\
\text { opthalmia. Root stock is soaked overnight and the } \\
\text { liquid is applied to treat conjunctivitis and ear ache. } \\
\text { Paste of the plant is used as poultices, haemostatic } \\
\text { and also used as antiseptics. Traditionally leaves are } \\
\text { torn into strips, used for stitching wounds after the } \\
\text { castration in domestic animals. }\end{array}$ \\
\hline $\begin{array}{l}\text { Morus macroura Miq. } \\
\text { [Moraceae]; Tangko sung (Ao) }\end{array}$ & $\begin{array}{l}\text { Latex and } \\
\text { fruits }\end{array}$ & $\begin{array}{l}\text { The fruit juice is used in the treatment of febrile } \\
\text { disease. Milky juice used in sores and wounds. Juice } \\
\text { extracts mixed with ash is used in inscription in } \\
\text { traditional clothes and woods. }\end{array}$ \\
\hline
\end{tabular}




\begin{tabular}{|c|c|c|}
\hline $\begin{array}{c}\text { Scientific Name [Family]/ Local } \\
\text { name }\end{array}$ & $\begin{array}{l}\text { Parts } \\
\text { used }\end{array}$ & Mode of Uses \\
\hline $\begin{array}{l}\text { Mussaenda macrophylla Wall. } \\
\text { [Rubiaceae]; Sapaklarinaro (Ao) }\end{array}$ & Leaves & $\begin{array}{l}\text { The paste of the leaves is haemostatic, aqueous } \\
\text { extract of the plant is used to cure mouth ulcer and as } \\
\text { appetizer. }\end{array}$ \\
\hline $\begin{array}{l}\text { Paederia foetida L. [Rubiaceae]; } \\
\text { Sunemli (Ao) }\end{array}$ & Whole plant & $\begin{array}{l}\text { It is Aphrodisiac, astringent, emetic, laxative and } \\
\text { tonic. Used in treatment of diarrhea, rheumatic pain, } \\
\text { toothache and inflammation of spleen. Leaves are } \\
\text { used for the treatment of digestive problems. Leaves } \\
\text { are also consumed as vegetables. }\end{array}$ \\
\hline $\begin{array}{l}\text { Panax psuedoginseng Wall. } \\
\text { [Araliaceae]; Takumtsu mozu (Ao) }\end{array}$ & Roots & $\begin{array}{l}\text { Roots dried and made into powder is taken orally for } \\
\text { the treatment of headache and convulsions. The plant } \\
\text { paste is applied to stop or slow down bleeding. } \\
\text { Sometimes its taken directly in nosebleeds, vomiting, } \\
\text { cough with blood or find blood in their urines. }\end{array}$ \\
\hline $\begin{array}{l}\text { Papaver somniferum L. } \\
\text { [Papaveraceae]; Kanitong (Ao) }\end{array}$ & Fruits & $\begin{array}{l}\text { Decoction of the fruit is used as an appetizer, } \\
\text { sedative, digestant, tonic, analgesic and used against } \\
\text { cough, dysentery, fever and anaemia. }\end{array}$ \\
\hline $\begin{array}{l}\text { Phlogacanthus pubinervius T. } \\
\text { Anderson. [Acanthaceae]; } \\
\text { Metecüse (Angami) }\end{array}$ & $\begin{array}{l}\text { Shoot and } \\
\text { leaves }\end{array}$ & $\begin{array}{l}\text { Decoction of fresh shoot and leaves is taken orally for } \\
\text { the treatment of cough, cold and fever. Young shoots } \\
\text { and inflorescenes are consumed as vegetables and are } \\
\text { also sold in markets. }\end{array}$ \\
\hline $\begin{array}{l}\text { Plantago asiatica subsp. erosa } \\
\text { (Wall.) Z.Yu Li [Plantaginaceae]; } \\
\text { Jangremriza/ Akaba (Ao) }\end{array}$ & Whole plant & $\begin{array}{l}\text { Leave paste applied on burns and in cuts. Whole } \\
\text { plant is astringent, cooling, febrifuge, diuretic and } \\
\text { tonic. Used in toothache and pile problem, eaten as } \\
\text { vegetable and sold in local market. Seeds are crushed } \\
\text { and made into paste is applied in sprain. The plant } \\
\text { also consumed as vegetables. }\end{array}$ \\
\hline $\begin{array}{l}\text { Persicaria chinensis }(\mathrm{L} .) \mathrm{H} . \\
\text { Gross }[\text { Polygonaceae]; Masu } \\
\text { malang (Ao) }\end{array}$ & Aerial parts & $\begin{array}{l}\text { The decoction of the whole plant is used as } \\
\text { depurative. The decoction is also used for the } \\
\text { treatment of eczema of the ears. The juice extracted } \\
\text { from the plant is used for the treatment of eye } \\
\text { diseases. }\end{array}$ \\
\hline $\begin{array}{l}\text { Rhus chinensis Mill. } \\
\text { [Anacardiaceae]; Tangmu (Ao) }\end{array}$ & Fruit & $\begin{array}{l}\text { Tusks of fruits mixed with water is used for bathing } \\
\text { to relieve from measles and prickly heat, it is also } \\
\text { mixed with chicken droppings and is drunk for the } \\
\text { treatment of food poisoning. Decoction of the fruit } \\
\text { tusk is used in indigestion, stomachache, allergy and } \\
\text { gastric troubles. }\end{array}$ \\
\hline $\begin{array}{l}\text { Ricinus communis L. } \\
\text { [Euphorbiaceae]; Phakowa/ } \\
\text { Yaklomala (Ao) }\end{array}$ & $\begin{array}{l}\text { Root, leaves } \\
\text { and seed oil }\end{array}$ & $\begin{array}{l}\text { Leave is warmed in the fire and applied to forehead } \\
\text { to relief from headache; paste applied as poultice in } \\
\text { boils and pimples. Seeds are roasted and eaten mixed } \\
\text { with husk of the Rhus simialata seed as purgative and } \\
\text { as antidote. The whole plant is used as fertilizer. }\end{array}$ \\
\hline $\begin{array}{l}\text { Rubia sikkimensis Kurz. } \\
\text { [Rubiaceae]; Awali/ Wailuk (Ao) }\end{array}$ & Roots & $\begin{array}{l}\text { Root paste is applied in snake bites as antidote. Root } \\
\text { extract mixed with plant extract of Eurya accuminata } \\
\text { gives brilliant red dye. }\end{array}$ \\
\hline $\begin{array}{l}\text { Saurauia napaulensis DC. } \\
\text { [Actinidiaceae]; Achijila (Ao) }\end{array}$ & $\begin{array}{l}\text { Leaves and } \\
\text { barks }\end{array}$ & $\begin{array}{l}\text { The plant Lecanthus peduncularis is mixed with the } \\
\text { bark of Saurauia napaulensis is crushed and the } \\
\text { resultant juice is consumed for the treatment of fever } \\
\text { and viral diseases. Leaves are eaten as vegetable. } \\
\text { Fruits are also eaten. }\end{array}$ \\
\hline $\begin{array}{l}\text { Senna alata (L.) Roxb. } \\
\text { [Leguminosae]; Aoktsü naro (Ao) }\end{array}$ & $\begin{array}{l}\text { Leaves, } \\
\text { seeds and } \\
\text { roots }\end{array}$ & $\begin{array}{l}\text { Leaf juice is applied for allergic and skin diseases. } \\
\text { Useful in asthma, bronchitis, rheumatism and } \\
\text { stomatitis. }\end{array}$ \\
\hline
\end{tabular}




\begin{tabular}{|c|c|c|}
\hline $\begin{array}{c}\text { Scientific Name [Family]/ Local } \\
\text { name }\end{array}$ & $\begin{array}{c}\text { Parts } \\
\text { used }\end{array}$ & Mode of Uses \\
\hline $\begin{array}{l}\text { Smilax glabra Roxb. } \\
\text { [Smilacaceae]; Mangkokangli } \\
\text { (Ao) }\end{array}$ & Leaves & $\begin{array}{l}\text { Leaf is consumed directly for the treatment against } \\
\text { venereal diseases and the leave paste is used to treat } \\
\text { skin rashes. The dendrils with spines are layed for } \\
\text { trapping wild boars and deers. After the injury the } \\
\text { animals cannot run for long and are ultimately killed } \\
\text { by the tribal hunters. }\end{array}$ \\
\hline $\begin{array}{l}\text { Smilax ovalifolia } \text { Roxb.ex D.Don } \\
\text { [Smilacaceae]; Mangkokangli } \\
\text { (Ao) }\end{array}$ & $\begin{array}{l}\text { Roots and } \\
\text { leaves }\end{array}$ & $\begin{array}{l}\text { A decoction of Leave and root is used for the } \\
\text { treatment of diarrhea and dysentry. }\end{array}$ \\
\hline $\begin{array}{l}\text { Solanum indicum L. } \\
\text { [Solanaceae]; Akho-longkok (Ao) }\end{array}$ & $\begin{array}{l}\text { Roots and } \\
\text { fruits }\end{array}$ & $\begin{array}{l}\text { Root paste is applied in skin diseases, leprosy, } \\
\text { toothache, asthma and bronchitis. Fruit is consumed } \\
\text { directly for the treatment of stomach ailments, fever, } \\
\text { and to lower blood pressure. }\end{array}$ \\
\hline $\begin{array}{l}\text { Solanum americanum } \\
\text { [Solanaceae]; Kumbo-wa (Ao) }\end{array}$ & Whole plant & $\begin{array}{l}\text { Plant paste is used in skin diseases, cough and to } \\
\text { achieve conception. Aqueous extract of the plant is } \\
\text { used to relieve muscular pain and the paste applied to } \\
\text { neutralize toxic substance of bee sting. Leaves and } \\
\text { fruits are used to treat Malaria, blood pressure and } \\
\text { bladder infections and eaten as vegetable. }\end{array}$ \\
\hline $\begin{array}{l}\text { Spermacoce neohispida Govaerts } \\
\text { [Rubiaceae]; Sunumra (Ao) }\end{array}$ & Whole plant & $\begin{array}{l}\text { The aerial parts of the plant is taken as febrifuge. It is } \\
\text { stimulant and tonic. The decoction of the root is taken } \\
\text { as mouthwash for toothache. Plant is made into paste } \\
\text { and applied to cuts as haemostatic. Sometimes leaves } \\
\text { are eaten as vegetables along with other plant. }\end{array}$ \\
\hline $\begin{array}{l}\text { Spilanthes acmella ( L.) L. } \\
\text { [Compositae]; Tefu mozitong (Ao) }\end{array}$ & Whole plant & $\begin{array}{l}\text { The decoction of the roots is used as purgative. It is } \\
\text { used for sore mouth and in toothache. Flowers are } \\
\text { crushed and consumed to treat in throat infection and } \\
\text { paralysis of tongue, for stammering in children. } \\
\text { Flowers increases the flow of saliva and useful in } \\
\text { fever. }\end{array}$ \\
\hline $\begin{array}{l}\text { Stephania glabra (Roxb.) Miers } \\
\text { (S. glandulifera Miers., S. rotunda } \\
\text { Lour.) [Menispermaceae]; Ketcha } \\
\text { moli (Ao) }\end{array}$ & Tuber & $\begin{array}{l}\text { Tubers are edible and is used to treat in fevers, } \\
\text { diarrhea, dyspepsia and as sedative. Plant paste is } \\
\text { applied to bone fracture and sprains. Leaves are fed } \\
\text { to cattle and goats. }\end{array}$ \\
\hline $\begin{array}{l}\text { Stereospermum chelonoides } \\
\text { (L.f.) DC. [Bignoniaceae]; } \\
\text { Mesusung (Ao) }\end{array}$ & $\begin{array}{l}\text { Root, bark, } \\
\text { leaves and } \\
\text { flowers. }\end{array}$ & $\begin{array}{l}\text { Plant extracted to juice is consumed to cure } \\
\text { dysentery, cholera and malarial fever. }\end{array}$ \\
\hline$\frac{\text { Terminalia chebula Retz. }}{\text { [Combretaceae]; Lingkatong (Ao) }}$ & Fruits & $\begin{array}{l}\text { The fruit is considered to have anti-bacterial and anti- } \\
\text { inflammatory properties. Fruit is usually dried and } \\
\text { taken which helps in digestion, improves appetite and } \\
\text { believed to improve memory as well. It is also used } \\
\text { during gastro-intestinal ailments, eye disease, skin } \\
\text { disease and weak eye sight. }\end{array}$ \\
\hline $\begin{array}{l}\text { Thysanolaena latifolia (Roxb.ex } \\
\text { Hornem.) Honda [Poaceae]; } \\
\text { Laptü/ Atsüng-tong (Ao) }\end{array}$ & Roots & Decoction of root is drunk during fever. \\
\hline $\begin{array}{l}\text { Tinospora sinensis (Lour.) Merr. } \\
\text { [Menispermaceae]; } \\
\text { Tsungrembang mozu (Ао) }\end{array}$ & Stem & $\begin{array}{l}\text { Stem is crushed and the juice obtained is used by the } \\
\text { tribe to cure various ailments such as malarial fever, } \\
\text { indigestion, skin diseases, piles, bronchitis, } \\
\text { impotency, jaundice, diarrhea, leprosy, acidity, } \\
\text { eruptive boils and cough. It is a diuretic, tonic and } \\
\text { acts as blood purifier. The leaves of the plant are } \\
\text { carried by tribal during hunting to drive away evil } \\
\text { spirits. }\end{array}$ \\
\hline
\end{tabular}




\begin{tabular}{|l|l|l|}
\hline $\begin{array}{l}\text { Scientific Name [Family]/ Local } \\
\text { name }\end{array}$ & \multicolumn{1}{c|}{$\begin{array}{c}\text { Parts } \\
\text { used }\end{array}$} & \multicolumn{1}{c|}{ Mode of Uses } \\
\hline $\begin{array}{l}\text { Viscum articulatum Burm.f. } \\
\text { [Santalaceae]; Teretzanglubawa } \\
\text { (Ao) }\end{array}$ & Aerial parts & $\begin{array}{l}\text { Plant is made into paste and is applied to set the bone } \\
\text { fractures and sprains. }\end{array}$ \\
\hline $\begin{array}{l}\text { Wrightia tinctoria R. Br. } \\
\text { [Apocynaceae]; Sapanpou (Ao) }\end{array}$ & $\begin{array}{l}\text { Bark and } \\
\text { seeds }\end{array}$ & $\begin{array}{l}\text { Bark paste is applied on skin diseases, ring worms, } \\
\text { leprosy. Decoction of bark is used to treat dysentery, } \\
\text { cholera abdominal pains, wounds, fever, piles, gout } \\
\text { and haemorrhage. Seed is roasted and eaten as } \\
\text { carminative and as laxative. }\end{array}$ \\
\hline $\begin{array}{l}\text { Zanthoxylum rhetsa } \text { (Roxb.) DC. } \\
\text { (Autaceae]; Mongret/ Mong Mong } \\
\text { Ao) }\end{array}$ & Bark, leaves seeds & $\begin{array}{l}\text { Leave and bark paste used as febrifuge and poultice; } \\
\text { used in rheumatism, asthma, bronchitis, malarial } \\
\text { fever. Dry seeds are taken to relieve from indigestion. } \\
\text { Fruits used as condiment and leaves as vegetables. } \\
\text { Crushed bark and fruits used for fish poisoning. }\end{array}$ \\
\hline $\begin{array}{l}\text { Zingiber officinale Roscoe } \\
\text { [Zingiberaceae]; Sungmok(Ao) }\end{array}$ & Rhizome & $\begin{array}{l}\text { Ginger is extensively used by the Nagas as flavouring } \\
\text { agents, condiments, medicinal, and in various } \\
\text { ceremonial and ritual performances. Paste of the } \\
\text { corms is applied for the treatment of bone fracture } \\
\text { and sprains; juice extract used as expectorant, } \\
\text { stimulant, carminatives, dyspepsia and tonic etc. }\end{array}$ \\
\hline
\end{tabular}

\section{DISCUSSION}

From the present Ethnobotanical study on Khiamniungan tribe of Tuensang Hill District of Nagaland, a total of 76 plant species were identified belonging to 48 families and 68 genera was recorded for the treatment of various diseases suppfer by them. Plant family with the highest medicinal plants in the study area used for various diseases treatment was Compositae (Asteraceae) with a total of 6 species, followed by Leguminosae and Lamiaceae each with five species. Again, Moraceae and Rubiaceae with 4 species each, Acanthaceae with 3 species, Apocynaceae, Dioscoreaceae, Fllacourtiaceae, Menispermaceae, Saurauriaceae, Smilaceae, Solanaceae and Zingiberaceae with 2 species each and the rest 29 families represented by single species. The distribution of habit groups for these plants has been presented in Figure 1. The plant parts which were mostly used as medicine were leaves, barks, roots, and whole plants followed by flowers, seeds, tender shoots, bulbs and fruits. Various plant parts collected from species like Abelmoschus moschatus, Allium sativum, Aristolochia indica, Acacia pennata, Bauhinia variegeta, Clerodendrum infortunatum, Commelina benghalensis and Rubia sikkimensis were used as antidote to cure snake bite and scorpion stings. Paste made of leaves of Chloranthus elatior were applied in the wounds of Tiger attacks and dog bites as antidote. Asparagus racemosus, Begonia flaviflora, Bidens biternata, Persicaria chinensis, Tinospora cordifolia, Paederia foedita and Papaver somniferum are used for curing diarrhea and dysentery. Species such as Asparagus officinalis, Bauhinia variegata, Begonia flaviflora, Spermacoce neohispida, Curculigo capitulate, Ficus hispida, Houttuynia cordata, Paederia foetida, Plantago major, Saurauia napaulensis and Solanum nigrum are consumed as vegetables. Species like Acacia pinnata, Artemesia nilagirica, Borreria hispida, Molineria capitulata and Leucosceptrum canum are used as haemostat. Crushed Barks and fruits of Zanthoxylum rhetsa is used for fish poisoning is also another indigenous practice of the tribe. Interestingly, latex of Alstonia scholaris is used by Khiamniungan tribe for ceremonial inscription and the wood is used for carving effigies kept in the grave of a rich man or warrior in the village. In ancient times when head hunting was 

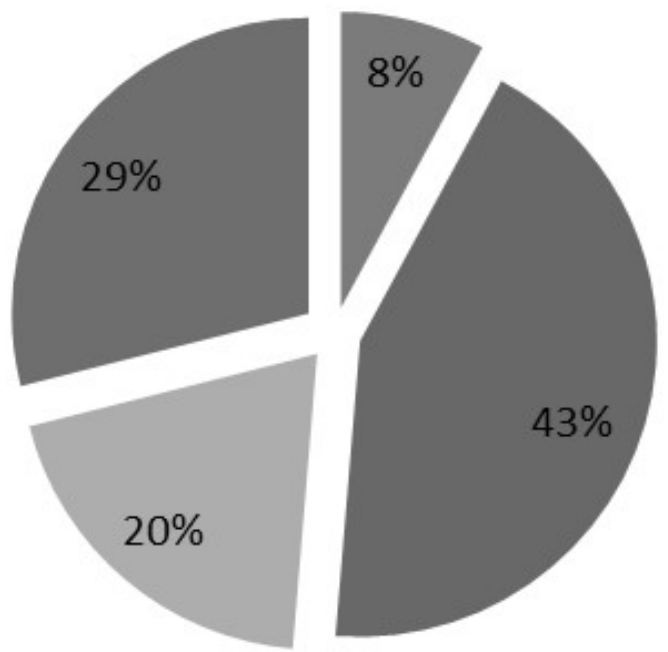

Climber 8\%

Herb 43\%

Shrub 20\%

Trees 29\%

Figure 1. Habit group representation among the recorded ethnomedicinal plants

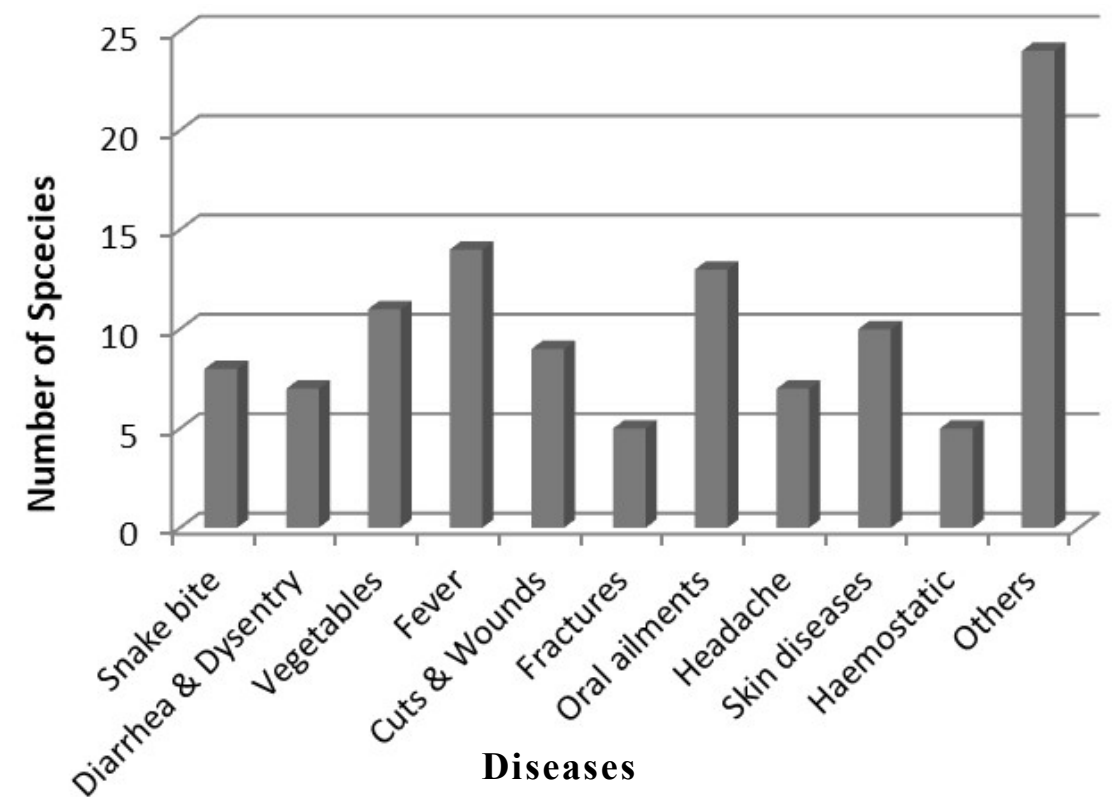

Figure 2. Number of species used by the indigenous people for medical efficacy against differnt diseases

still prevalent, Tribal peoples hang the skulls under the tree, Erythrina arborescenes as a trophy. Alders were erected under this tree to perform various rituals by the community priest. Traditionally tribal people used species such as Hypericum japonicum and Tinospora cordifolia to drive away evil spirits. As from the above study, it is evident that the use of medicinal plants for treatment of various diseases by the Khiamniungan tribe has always been known to the tribe and has gained knowledge that were passed from generation to generation through oral tradition and practices. Plant parts obtained from the species like Plantago asiatic subsp. erosa, Viscum articulatum and Zingiber officinale are also used for the treatment of bone fracture and sprains. Many of these 
plants are also used as vegetable and fruits by the local people. Number of plants used against different diseases has been presented in Figure 2. Due to globalization and industrialization, many young generations has the tendency to migrate to cities and to discard their traditional life style. There is a high risk of losing such valuable traditional knowledge and culture. Therefore, it is very important to protect, conserve and document such valuable information and practices of the indigenous tribe.

\section{Acknowledgements}

The authors are greatly indebted to the people of Khiamniungan tribe of Tuensang district including the medicine practitioners and village elders for sharing their experiences and valuable knowledge about the usage of different plant species for medicinal purpose and also to the village heads and councils for granting permission to gather information around the village and forest area for documentation.

\section{LITERATURE CITED}

Abbasi, A.M.; Khan, M.A.; Ahmad, M. \& Zafar, M. 2012. Medicinal plant biodiversity of lesser Himalayas-Pakistan. Springer. Pp. 17 - 36.

BSI 2019. Viewed at https://bsi.gov.in/content/263_1_EthnobotanicalStudies.aspx

FSI 2011. India State Forest Report 2011. Forest Survey of India, Dehra Dun.

Grierson, A.J.C. \& Long, D.G. 1983-1987. Flora of Bhutan. Vol. I. Parts I,II \& III. Royal Botanic Garden, Edinburg.

Hara, H. \& Williams, L.H.J. 1979. An enumeration of the flowering plants of Nepal. Vol. II. British Museum (Natural History), London.

Hara, H.; Chater, A.Q. \& Williams, L.H.J. 1982. An enumeration of the flowering plants of Nepal. Vol. III. British Museum (Natural History), London.

Hara, H.; Stearn, W.T. \& Williams, L.H.J. 1978. An enumeration of the flowering plants of Nepal. Vol. I. British Museum (Natural History), London.

Hooker, J.D. 1872-1897. The Flora of British India. Vol. I-VII. L.Reeve \& Co. Ltd., Kent, London.

http://www.theplantlist.org

Jain, S.K. \& Rao, R.R. 1977. A handbook of field and herbarium methods. Today and tomorrows publication, New Delhi.

Kanjilal, U.N.; Kanjilal, P.C. \& Das, A. 1938. Flora of Assam, Vol. 2, Assam Govt. Press, Shillong.

Kanjilal, U.N.; Kanjilal, P.C.; Das. A. \& Dey, R.N. 1939. Flora of Assam, Vol. 3, Assam Govt. Govt. Press, Shillong.

Kanjilal, U.N.; Kanjilal, P.C; Das, A, \& Dey, R.N. 1940. Flora of Assam, Vol. 4, Assam Govt. Govt. Press, Shillong.

Kanjilal, U.N.; Kanjilal, P.C; Das. A. \& Purkaystha, C. 1934. Flora of Assam, Vol. 1, Assam Govt. Press, Shillong.

Noltie, H.J. 1994, 2000. Flora of Bhutan. Vol. III. Parts I \& II, Royal Botanic Garden, Edinburg.

Pandey, K.A. \& Tripathi, Y.C. 2017. Ethnobotany and its relevance in contemporary research. J. Med. Pl. Stud., 5(3): 123 - 129. 
Pankhurst, R. 1965. An historical examination of traditional Ethiopian medicine and surgery. Ethiop. Med. J., 3: 157 - 172.

Park, H.L.; Lee, H.S. \& Shin, B.S. 2012. Traditional medicine in China, Korea, and Japan: a brief introduction and comparison. Evidence-Based Complementary and Alternative Medicine, 2012: 7 - 9 .

Prain, D. 1903. Bengal plants. Vol. I \& II. West, Newman \& Co., London.

Shah N.C. 2008. Ethnobotany in India. In: H. Selin (eds), Encyclopaedia of the History of Science, Technology, and Medicine in Non-Western Cultures. Springer, Dordrecht. (https://doi.org/10.1007/978-1-4020-4425-0_8578)

Sofowora, A. 1982. Medicinal Plants and Traditional Medicine in Africa. John Wiley \& Sons, New York, USA.

WHO 1999. Consultation meeting on traditional medicine and modern medicine: harmonizing the two approaches. WHO, Geneva, Switzerland.

WHO 2001. Legal Status of Traditional Medicine and Complementary/Alternative Medicine: A Worldwide Review. WHO, Geneva, Switzerland. 